\title{
Role of the medial prefrontal cortex in $5-\mathrm{HT}_{1 \mathrm{~A}}$ receptor-induced inhibition of 5-HT neuronal activity in the rat
}

\author{
${ }^{*, 1}$ Mihály Hajós, ${ }^{1}$ Éva Hajós-Korcsok \& ${ }^{1}$ Trevor Sharp
}

${ }^{1}$ Oxford University Department of Clinical Pharmacology, Radcliffe Infirmary, Woodstock Road, Oxford, OX2 6HE

1 We examined the involvement of the frontal cortex in the 5- $\mathrm{HT}_{1 \mathrm{~A}}$ receptor-induced inhibition of 5-HT neurones in the dorsal raphe nucleus (DRN) of the anaesthetized rat using single-unit recordings complemented by Fos-immunocytochemistry.

2 Both transection of the frontal cortex as well as ablation of the medial region of the prefrontal cortex (mPFC) significantly attenuated the inhibition of 5-HT neurones induced by systemic administration of the 5- $\mathrm{HT}_{1 \mathrm{~A}}$ receptor agonist, 8-OH-DPAT $\left(0.5-16 \mu \mathrm{g} \mathrm{kg}^{-1}\right.$, i.v.). In comparison, the response to 8-OH-DPAT was not altered by ablation of the parietal cortex. The inhibitory effect of 8-OH-DPAT was reversed by the 5- $\mathrm{HT}_{1 \mathrm{~A}}$ receptor antagonist, WAY $100635\left(0.1 \mathrm{mg} \mathrm{kg}^{-1}\right.$, i.v. $)$ in all neurones tested.

3 In contrast, cortical transection did not alter the sensitivity of 5-HT neurones to iontophoretic application of 8-OH-DPAT into the DRN. Similarly, cortical transection did not alter the sensitivity of 5-HT neurones to systemic administration of the selective 5-HT reuptake inhibitor, paroxetine (0.1-0.8 $\mathrm{mg} \mathrm{kg}^{-1}$, i.v.).

4 8-OH-DPAT evoked excitation of mPFC neurones at doses $\left(0.5-32 \mu \mathrm{g} \mathrm{kg}^{-1}\right.$, i.v. $)$ in the range of those which inhibited 5-HT cell firing. At higher doses $\left(32-512 \mu \mathrm{g} \mathrm{kg}^{-1}\right.$, i.v.) 8-OH-DPAT inhibited mPFC neurones. 8-OH-DPAT $\left(0.1 \mathrm{mg} \mathrm{kg}^{-1}\right.$, s.c.) also induced Fos expression in the mPFC. The neuronal excitation and inhibition, as well as the Fos expression, were antagonized by WAY 100635.

5 These data add further support to the view that the inhibitory effect of 5-HT $1 \mathrm{~A}$ receptor agonists on the firing activity of DRN 5-HT neurones involves, in part, activation of a 5-HT $1 \mathrm{~A}$ receptormediated postsynaptic feedback loop centred on the mPFC.

Keywords: Serotonin; 5- $\mathrm{HT}_{1 \mathrm{~A}}$ receptor; 8-OH-DPAT; WAY 100635; paroxetine; medial prefrontal cortex; dorsal raphe nucleus

Abbreviations: $\mathrm{Cg} 3$, cingulate cortex area 3; $\mathrm{CPu}$, caudate putamen; DRN, dorsal raphe nucleus; Fos-LI, Fos-like immunoreactivity; Fr1, frontal cortex area 1; 5-HT, 5-hydroxytryptamine; IL, infralimbic cortex; mPFC, medial prefrontal cortex; 8-OH-DPAT, 8-hydroxy-2-(di-n-propylamino)tetralin HBr; SSRI, selective 5-HT reuptake inhibitor

\section{Introduction}

It is well established that exogenous $5-\mathrm{HT}$ or $5-\mathrm{HT}_{1 \mathrm{~A}}$ receptor agonists inhibit the activity of midbrain 5-HT neurones via activation of somatodendritic $5-\mathrm{HT}_{1 \mathrm{~A}}$ receptors. Thus, local iontophoretic application of 5-HT or 5-HT $1 \mathrm{~A}$ receptor agonists like 8-OH-DPAT lead to cessation of spontaneous firing of 5HT neurones recorded in the dorsal raphe nucleus (DRN) of both anaesthetized and awake animals (Aghajanian et al., 1972; Sprouse \& Aghajanian, 1987; Levine \& Jacobs, 1992). Furthermore, these treatments have the same effect when applied directly onto 5-HT neurones recorded in brain slice or dissociated cell preparations (Aghajanian \& Lakoski, 1984; Penington et al., 1993a,b). The inhibitory effect of selective 5HT re-uptake inhibitor (SSRI) antidepressants on 5-HT neurones has also been attributed to the activation of somatodendritic 5- $\mathrm{HT}_{1 \mathrm{~A}}$ autoreceptors (Blier \& de Montigny, 1983; Gartside et al., 1995; Hajós et al., 1995a), and it is presumed that this inhibition contributes to the lack of antidepressant effect early on in the treatment (Blier \& de Montigny, 1994).

Interestingly, there is accumulating evidence that $5-\mathrm{HT}_{1 \mathrm{~A}}$ receptor agonists might inhibit the activity of 5-HT neurones in the DRN not only via somatodendritic 5- $\mathrm{HT}_{1 \mathrm{~A}}$ auto-

*Author for correspondence;

E-mail: mihaly.hajos@clinical-pharmacology.oxford.ac.uk receptors but also $5-\mathrm{HT}_{1 \mathrm{~A}}$ receptors located at other sites. Earlier studies reported that chronic treatment of rats with lithium (Blier et al., 1987), the 5-HT $\mathrm{HA}_{1 \mathrm{~A}}$ receptor agonists gepirone or ipsapirone (Blier \& de Montigny, 1987; Schechter et al., 1990), or SSRIs (Blier \& de Montigny, 1980; Jolas et al., 1994), attenuates the inhibitory effect on 5-HT neurones of iontophoretically administered 5-HT or 8-OH-DPAT. Similar results were obtained when $5-\mathrm{HT}_{1 \mathrm{~A}}$ receptor agonists are applied to brain slices prepared from antidepressant treated animals (Jolas et al., 1994). In contrast, antidepressant treatment does not modify the inhibitory effect of $8-\mathrm{OH}$ DPAT when the drug is administered systemically (Blier \& de Montigny, 1987; Schechter et al., 1990; Jolas et al., 1994). These findings suggest that (i) $5-\mathrm{HT}_{1 \mathrm{~A}}$ receptors other than those located on the somatodendrites of 5-HT neurones might regulate 5-HT neuronal activity and (ii) in contrast to somatodendritic $5-\mathrm{HT}_{1 \mathrm{~A}}$ receptors, these $5-\mathrm{HT}_{1 \mathrm{~A}}$ receptors (presumably located postsynaptically in relation to 5-HT nerve terminals) do not desensitize upon chronic antidepressant treatment.

A recent paper reported more direct evidence for a role of postsynaptic $5-\mathrm{HT}_{1 \mathrm{~A}}$ receptors in the inhibition of 5-HT neurones by systemically administered 8-OH-DPAT. Thus, Ceci et al. (1994) reported that after an acute, deep transection of the frontal cortex and forebrain, the dose-response curve for 
the inhibitory effect of 8-OH-DPAT on the firing 5-HT neurones was shifted 10 fold to the right. Although this study did not resolve the anatomical location of the postsynaptic 5$\mathrm{HT}_{1 \mathrm{~A}}$ receptors, the dense population of $5-\mathrm{HT}_{1 \mathrm{~A}}$ receptors located in the medial prefrontal cortex (mPFC; Pompeiano et al., 1992; Kia et al, 1996) was a likely candidate. Interestingly, we have recently demonstrated that there is a direct projection from the mPFC to the DRN, and that electrical stimulation of this pathway inhibited most DRN 5-HT neurones tested (Hajós et al., 1998b).

Here we further investigate the role of the frontal cortex, and the mPFC in particular, in the 8-OH-DPAT-induced inhibition of 5-HT neuronal activity. Experiments include the use of animals with acute cortical/mPFC lesions to test of the effects of 8-OH-DPAT and the SSRI, paroxetine administered systemically or iontophoretically on DRN 5-HT neurones. The effects of 8-OH-DPAT on neuronal activity in the mPFC was measured electrophysiologically and by Fos protein immunocytochemistry. In most experiments the effect of 8-OH-DPAT was validated pharmacologically using the selective $5-\mathrm{HT}_{1 \mathrm{~A}}$ receptor antagonist, WAY 100635 (Fletcher et al., 1996). A preliminary account of the findings was recently presented to the Forum of European Neuroscience (Hajós et al., 1998a).

\section{Methods}

\section{Animals and surgical methods}

Male Sprague-Dawley rats (265-285 g, Harlan Olac, Bicester, U.K.) were anaesthetized with chloral hydrate $\left(450 \mathrm{mg} \mathrm{kg}^{-1}\right.$, i.p.) and mounted in a stereotaxic frame (Kopf) with the incisor bar set at $-3.3 \mathrm{~mm}$. Body temperature of the animals was maintained at $36^{\circ} \mathrm{C}$ throughout the experiment by a homeothermic heating pad connected to a rectal probe. A lateral tail vein was cannulated for administration of drugs and additional doses of anaesthetic. The skull was exposed and craniotomy was performed above the region of the DRN or mPFC. When iontophoretic multibarrel electrodes were used for electrophysiological recordings from DRN, the superior sagittal sinus was ligated and cut, as we described previously (Hajós et al., 1996a).

Transection of the forebrain was performed using a fine needle $(0.6 \mathrm{~mm}$ diameter $)$ which was stereotaxically positioned $1 \mathrm{~mm}$ anterior to bregma, $7 \mathrm{~mm}$ below the dura (Paxinos \& Watson, 1986) and then moved from the midline laterally to both sides (without damaging the sinus). Ablation of the mPFC were performed bilaterally with a thin ' $\mathrm{r}$ ' formed needle: the cortical areas removed were cingulate cortex area 1 and 3 (or prelimbic area), the medial aspect of the frontal cortex area 2, medial orbital cortex and the infralimbic cortex (IL). Stereotaxic co-ordinates of the lesion were: lateral 0 to $1 \mathrm{~mm}$ from the midline, anterior 1.7 to $4.2 \mathrm{~mm}$ from bregma, and 0 to $5 \mathrm{~mm}$ ventral from the dura ( 0 to $3 \mathrm{~mm}$ at the most anterior lesion and 0 to $5 \mathrm{~mm}$ at anterior $2.20 \mathrm{~mm}$ ). Ablations were also performed in the parietal cortex: the parietal cortex area 1 and, partly, the temporal cortex area 1 were surgically removed at the stereotaxic co-ordinates posterior 1.8 to $4.3 \mathrm{~mm}$ from bregma. Electrophysiological recordings in the DRN were made before and $40-50 \mathrm{~min}$ after the transection or ablation.

\section{Extracellular recordings}

Extracellular recordings were performed with single barrel or five barrel, iontophoretic glass electrodes as described before
(Hajós et al., 1995b; 1998b). Single barrel electrodes were filled with $2 \mathrm{M} \mathrm{NaCl}$ saturated with pontamine sky blue dye and had in vitro impedances of $3-10 \mathrm{M} \Omega$. The central barrel of prefabricated iontophoretic electrodes was used for extracellular recordings and the side barrels were filled with saline or drug solutions (impedances of $30-50 \mathrm{M} \Omega$ ). Stereotaxic coordinates for the DRN were: $7.8 \mathrm{~mm}$ posterior from the bregma, lateral $0 \mathrm{~mm}$ and $5-6 \mathrm{~mm}$ below dura (Paxinos \& Watson, 1986). Neurones of the $\mathrm{mPFC}$ were recorded $2.7 \mathrm{~mm}$ anterior to bregma, and $0.5-0.7 \mathrm{~mm}$ lateral and $2.5-5 \mathrm{~mm}$ below the dura.

Single unit potentials were passed through a high inputimpedance amplifier and filters $(300 \mathrm{~Hz}$ to $5 \mathrm{kHz}$ or $10 \mathrm{kHz}$ band-pass). The resulting signal was relayed to an audio monitor, oscilloscope and a chart recorder (Gould), and was discriminated from background noise by a window discriminator (Digitimer). The discriminator output pulses were computed on-line using a DAT 1401plus interface system and Spike2 software (Cambridge Electronic Design). Data were also stored on digital audio tape for off-line analysis.

At the end of each experiment the position of the electrode tip was marked by iontophoretic ejection of pontamine sky blue dye $(20 \mu \mathrm{A}$ negative current, $1 \mathrm{~Hz}$ pulses of $300 \mu \mathrm{s}$ duration for $10 \mathrm{~min}$ ) and the brains were subjected to routine histological examination.

\section{DRN 5-HT neurones}

Neurones recorded in the DRN were presumed to be 5-HT containing neurones if (i) they discharged broad action potentials in a slow $(0.1-3.5 \mathrm{~Hz})$ and regular fashion, and (ii) individual action potentials showed prominent positive deflection which was followed by a negative or negative/ positive transient and the first positive and negative deflections had a duration longer than $1.4 \mathrm{~ms}$ (Aghajanian et al., 1978; Aghajanian \& VanderMaelen, 1982; Hajós et al., 1995b). The majority of 5-HT neurones included in this study discharged only single spikes but some 5-HT neurones which discharged spikes in brief bursts were also monitored (Hajós et al, 1995b; 1996a). Data from all 5-HT neurones were included in the final analysis since the bursting 5-HT neurones do not differ from single-spiking 5-HT neurones in terms of their response to 5$\mathrm{HT}_{1 \mathrm{~A}}$ agonist or 5-HT re-uptake inhibitor (Hajós et al., 1995b; 1996b).

\section{MPFC neurones}

The majority of the mPFC neurones included in the study (11 of 13) had a slow firing rate $(0.1-0.8 \mathrm{~Hz})$ although two neurones had higher firing rates $(2.7$ and $7.8 \mathrm{~Hz})$. Most of the cortical neurones had an irregular firing pattern and many of them showed burst activity (firing spike doublets and triplets within a short time interval) as described previously (McCormick et al., 1993). The action potential duration of cortical neurones (recorded extracellularly) was over $1 \mathrm{~ms}$, indicating that they were probably pyramidal neurones (McCormick et al., 1993).

\section{Drug administration protocols}

Neurones were identified on the basis of their neurophysiological characteristics (see above) and their baseline firing activity was recorded for at least $3 \mathrm{~min}$ before drug application. For systemic administration, drugs were injected i.v. in doubling doses at approximately 2 min intervals. Cumulative dose-response curves for 8-OH-DPAT or parox- 
etine were obtained from one neurone per animal. In most experiments WAY 100635 was administered as a single dose (0.1 $\mathrm{mg} \mathrm{kg}^{-1}$, i.v.) about $2 \mathrm{~min}$ following the last dose of 8 OH-DPAT or paroxetine.

Local bilateral microinjections of 8-OH-DPAT $\left(1 \mu \mathrm{g} \mu \mathrm{l}^{-1}\right.$ in each side) into the $\mathrm{mPFC}(2.7 \mathrm{~mm}$ anterior, $0.5 \mathrm{~mm}$ lateral from bregma and $4.4 \mathrm{~mm}$ ventral from the dura) or caudate putamen $(\mathrm{CPu}: 1.0 \mathrm{~mm}$ anterior, $2.5 \mathrm{~mm}$ lateral from bregma and $5.5 \mathrm{~mm}$ ventral from the dura) were performed with a calibrated glass pipette connected to a syringe via a plastic tube and switch. A few crystals of pontamine sky blue dye were dissolved with 8-OH-DPAT to help detect the injection site.

For iontophoretic application of drugs (IP-X5; Neuro Data), a five barrel micropipette was used (see above). The side barrels were filled with either 8-OH-DPAT ( $5 \mathrm{~mm}$ in $0.2 \mathrm{M}$ $\mathrm{NaCl}, 5 \mathrm{nA}$ negative retaining current) or WAY 100635 (5 mM in $0.2 \mathrm{M} \mathrm{NaCl}, 5 \mathrm{nA}$ negative retaining current). One of the side barrels was filled with $2 \mathrm{M} \mathrm{NaCl}$ solution, and used for automatic current balancing. For the iontophoretic experiments, the baseline firing rate was determined during at least $6 \times 10 \mathrm{~s}$ sample periods before application of drugs, and at least $3 \times 10 \mathrm{~s}$ sample periods during each application. Iontophoretic application of 8-OH-DPAT was performed with currents of $2.5,5,10$ and $20 \mathrm{nA}$, each current being tested twice on each neurone. The same iontophoretic electrodes were used before and after the transection.

\section{Analysis of electrophysiological data}

Neuronal activity is presented mostly in the form of firing rate histograms. The distribution of spikes was analysed by construction of interspike interval histograms (collecting $200-500$ intervals per histogram) both under basal conditions and following drug treatment. The change in firing is calculated as the difference between the pre- and post-drug firing rate, and expressed as a percentage of the pre-drug firing rate. Individual $\mathrm{ED}_{50}$ values were determined by interpolation of percentage inhibition curves constructed on a semi-log plot.

Data are presented as mean \pm s.e.m. (n) values throughout. Differences between groups were assessed by two-way ANOVA or unpaired Student's $t$-test as appropriate. Significance at the $95 \%$ level or above is reported.

\section{Fos immunocytochemistry}

Rats were treated with saline $(n=5)$ or 8-OH-DPAT, $0.1 \mathrm{mg} \mathrm{kg}^{-1} \quad(n=7)$ subcutaneously (s.c.) in volumes of $1 \mathrm{ml} \mathrm{kg}{ }^{-1}$. The selective $5-\mathrm{HT}_{1 \mathrm{~A}}$ receptor antagonist WAY 100635 (1 $\mathrm{mg} \mathrm{kg}^{-1}$, s.c.) was administered $10 \mathrm{~min}$ before 8OH-DPAT $\left(0.1 \mathrm{mg} \mathrm{kg}^{-1}\right.$, s.c.) treatment $(n=4)$. Two hours after the saline or 8-OH-DPAT injection animals were killed with an overdose of pentobarbitone sodium $\left(200 \mathrm{mg} \mathrm{kg}^{-1}\right.$, i.p.) and perfused trans-cardially with $100 \mathrm{ml}$ saline followed by $100 \mathrm{ml} 4 \%$ paraformaldehyde (in $0.1 \mathrm{M}$ sodium phosphate buffer). Brains were then removed and processed for localization of Fos-like immunoreactivity.

Fos-like immunoreactivity (Fos-LI) was detected using a method described previously (Moorman et al., 1995). In brief, sections were incubated in a polyclonal primary antiserum (dilution 1:2000 in immunobuffer containing $0.1 \mathrm{M} \mathrm{NaCl}, \mathrm{KCl}$ $5 \mathrm{mM} \quad \mathrm{Na}_{2} \mathrm{HPO}_{4} 8 \mathrm{mM} \quad \mathrm{NaH}_{2} \mathrm{PO}_{4} 15 \mathrm{~mm}$ Tris- $\mathrm{HCl} 10 \mathrm{~mm}$, $0.3 \%$ Triton-X-100, $0.04 \%$ Thimerosal; $\mathrm{pH}$ 7.4). The polyclonal antibody (Cambridge Research Biochemicals, Cambridge, U.K.) was raised in sheep against residues 2-16 of the N-terminal region of the Fos molecule, and recognizes Fos and related antigens. After washing, sections were further incubated in biotinylated rabbit anti-sheep secondary antiserum (Vector Laboratories, U.K.; dilution 1:200). An avidinbiotin-horseradish peroxidase procedure with diaminobenzidine as the chromogen was used to visualize Fos-LI.

Two consecutive sections of the frontal cortex were taken from each animal, and in each section Fos positive cells were counted bilaterally in a tissue area of $0.09 \mathrm{~mm}^{2}$ in the following regions (as shown on Figure 7): infralimbic cortex (IL), cingulate cortex $(\mathrm{Cg} 3)$ and frontal cortex $(\mathrm{Fr} 1)$. The average of the four counts per rat was analysed by one-way ANOVA with repeated measures followed by post hoc Dunnett $t$-test.

\section{Materials}

The following drugs (with sources) were used: chloral hydrate (Sigma), 8-OH-DPAT (8-hydroxy-2-(di-n-propylamino)tetralin $\mathrm{HBr}$; $\mathrm{RBI}$ ), paroxetine (SmithKline Beecham, Harlow, U.K.), pentobarbitone sodium (Euthatal, Rhone Merieux Ltd., U.K.) and WAY 100635 (N-[2-[4-(2-methoxyphenyl)-1piperazinyl]-N-(2-pyridinyl) cyclohexane-carboxamide. $3 \mathrm{HCl}$; Wyeth Research Ltd., U.K.). Chloral hydrate and 8-OHDPAT were dissolved in $0.9 \%$ saline, and paroxetine in water.

\section{Results}

Effect of 8-OH-DPAT and paroxetine on the activity of 5-HT neurones in control and cortically lesioned rats

Systemic administration of drugs Administration of 8-OHDPAT $\left(0.5-16 \mu \mathrm{g} \mathrm{kg}^{-1}\right.$, i.v.) inhibited all 5-HT neurones tested in control rats $(n=6)$ and rats with cortical lesions (transection plus mPFC ablation; $n=8$ ) (Figure 1). However, in both cortically-transected and $\mathrm{mPFC}$-ablated rats, only higher doses of 8-OH-DPAT inhibited 5-HT neurones when compared to unlesioned controls. Both lesions shifted the 8OH-DPAT dose response curves about four times to the right (Figure 2). $\quad \mathrm{ED}_{50}$ values for 8-OH-DPAT were $0.92 \pm$ $0.17 \mu \mathrm{g} \mathrm{kg}^{-1}$ (i.v.) in controls $(n=6), 3.38 \pm 0.24 \mu \mathrm{g} \mathrm{kg}^{-1}$ (i.v.) in cortically transected rats $(n=4)$ and $6.25 \pm$ $2.01 \mu \mathrm{g} \mathrm{kg}^{-1}$ (i.v.) in mPFC-ablated rats $(n=4)$. Statistical analysis of the $\mathrm{ED}_{50}$ data revealed a significant main effect of lesion $\left(\mathrm{F}_{2,11}=23.5 ; \quad P<0.0001\right)$ and doses $\left(\mathrm{F}_{5,55}=52.0\right.$; $P<0.0001$ ) and a significant (lesion and doses) interaction $\left(\mathrm{F}_{10,55}=4.5 ; P<0.0001\right)$. The inhibitory effect of 8-OH-DPAT on 5-HT neurones was reversed by the administration of WAY $100635\left(0.1 \mathrm{mg} \mathrm{kg}^{-1}\right.$, i.v. $)$ in all tested control $(n=6)$ and lesioned $(n=6)$ rats (Figure 1).

In a subsequent study, ablation of the parietal cortex was performed. In contrast to the effect of ablation of the mPFC, this procedure did not modify the inhibitory effect of the systemically (i.v.) administered 8-OH-DPAT: $\mathrm{ED}_{50}$ values were $1.56 \pm 0.5 \mu \mathrm{g} \mathrm{kg}^{-1}$ (i.v.) in controls $(n=4)$ and $1.51 \pm$ $0.70 \mu \mathrm{g} \mathrm{kg}^{-1}$ (i.v.) in parietal cortex-ablated rats $(n=4)$.

In contrast to 8-OH-DPAT, paroxetine $\left(0.1-0.8 \mathrm{mg} \mathrm{kg}^{-1}\right.$, i.v.) was found to be equally potent at inhibiting the firing activity of 5-HT neurones in control rats $(n=6)$ and rats with cortical transections $(n=5)$ (Figure 3$)$. The paroxetine-induced inhibition was reversed by WAY $100635\left(0.1 \mathrm{mg} \mathrm{kg}^{-1}\right.$, i.v. $)$ in all cases tested.

Neither transection of the frontal cortex nor ablation of the $\mathrm{mPFC}$ altered the electrophysiological characteristics of the 5HT neurones in terms of basal firing rate, regularity or incidence of bursting activity of 5-HT neurones (data not shown). 
a

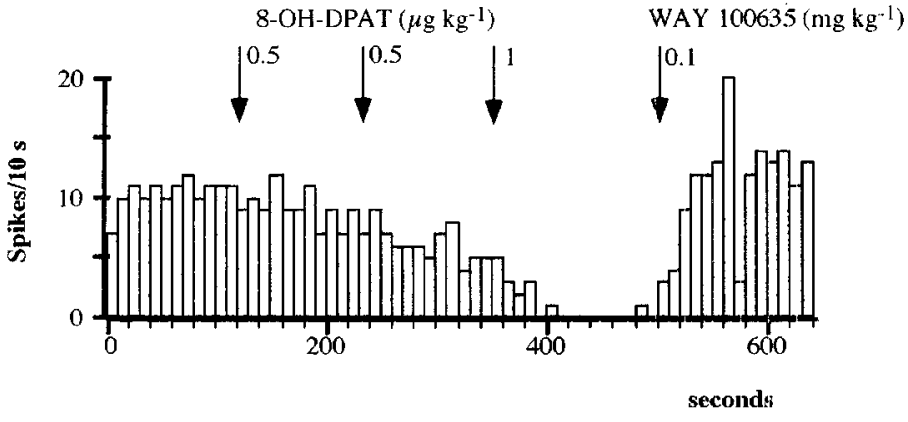

b

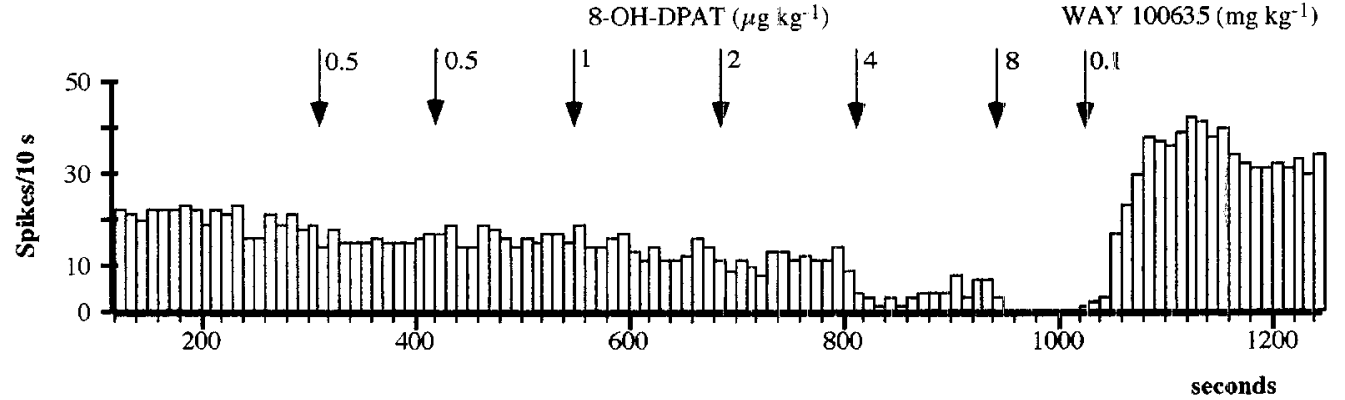

Figure 1 Firing rate histograms of two 5-HT neurones recorded from either an intact control rat (a) or from a rat which underwent a mPFC ablation (b). Arrows indicate i.v. administration of 8-OH-DPAT or WAY 100635.

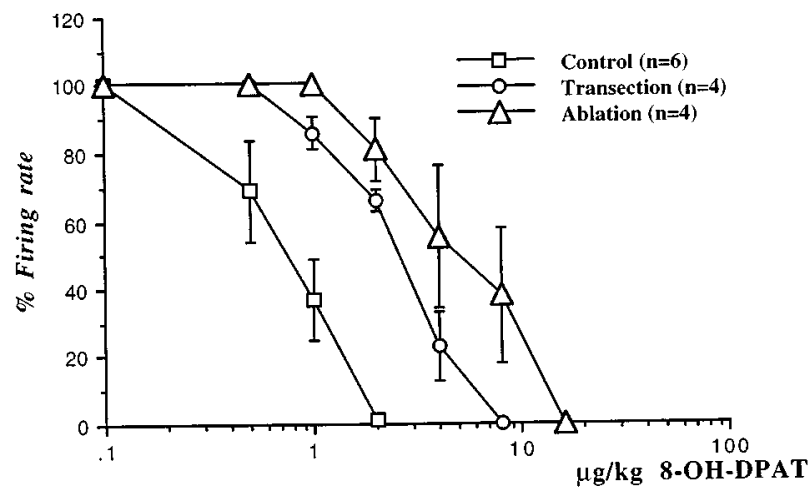

Figure 2 Inhibition of activity of 5-HT neurones (expressed as percentage of firing rate) induced by cumulative doses of i.v. administered 8-OH-DPAT in control rats and in rats after transection of the frontal cortex (Transection) or ablation of the medial prefrontal cortex (Ablation).

Microiontophoretic administration of drugs The possibility that cortical transection induced a change in the sensitivity of somatodendritic 5- $\mathrm{HT}_{1 \mathrm{~A}}$ receptors of 5-HT neurones was determined by microiontophoretic application of 8-OH-DPAT into the DRN. The iontophoretic current necessary to inhibit 5-HT neurones were determined before (12 neurones) and after (14 neurones) transection in four rats (using the same iontophoretic electrode before and after the transection. Iontophoretic application of 8-OH-DPAT $(2.5,5,10$ and $20 \mathrm{nA}$ ) produced a current-dependent inhibition of the activity of 5-HT neurones which was comparable in potency before and after cortical transection (Figure 4). The mean current which produced $50 \%$ inhibition of DRN neuronal firing activity being $3.3 \pm 0.7 \mathrm{nA}$ and $3.7 \pm 0.7 \mathrm{nA}$ in control and lesioned rats, respectively. The 8-OH-DPAT inhibition was

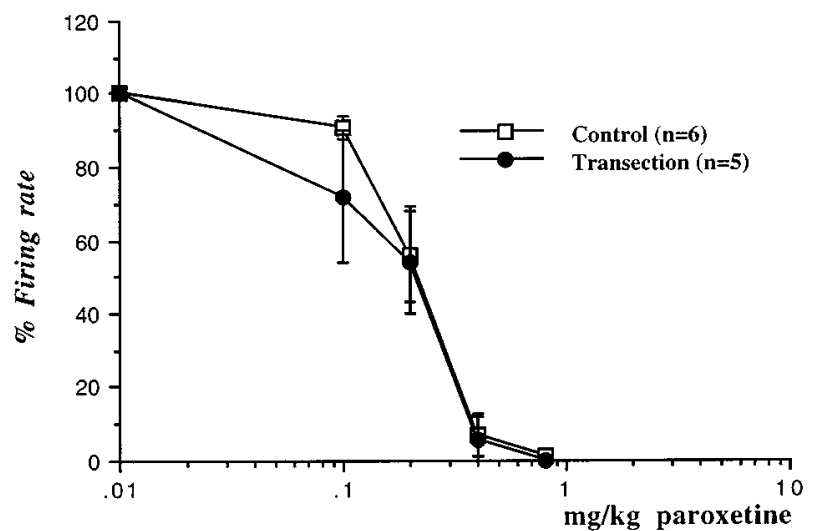

Figure 3 Dose-response curves showing the inhibitory effect of i.v. administration of paroxetine on the firing rate of 5-HT neurones in control and cortically transected rats.

readily reversed or antagonized by either systemic or iontophoretic application of WAY 100635 (Figure 4).

Effect of bilateral microinjection of 8-OH-DPAT into the $\mathrm{MPFC}$ and $\mathrm{CPu}$ on the activity of DRN 5-HT neurones

Bilateral local microinjection of 8-OH-DPAT $\left(1 \mu \mathrm{g} \mu \mathrm{l}^{-1}\right)$ into the $\mathrm{mPFC}$ or $\mathrm{CPu}$ inhibited most of the 5-HT neurones tested (mPFC injection: 6/7 neurones, mean inhibition $83 \pm 11 \%$; $\mathrm{CPu}$ injection: $4 / 4$ neurones, mean inhibition $75 \pm 18 \%)$. The inhibition had a short latency $(<1 \mathrm{~min})$ and in some neurones it led to total cessation of firing $(4 / 7$ and $2 / 4$ neurones after $\mathrm{mPFC}$ and $\mathrm{CPu}$ microinjection, respectively, Figure 5). The 8$\mathrm{OH}$-DPAT-induced inhibition of 5-HT neurones was reversed 
a

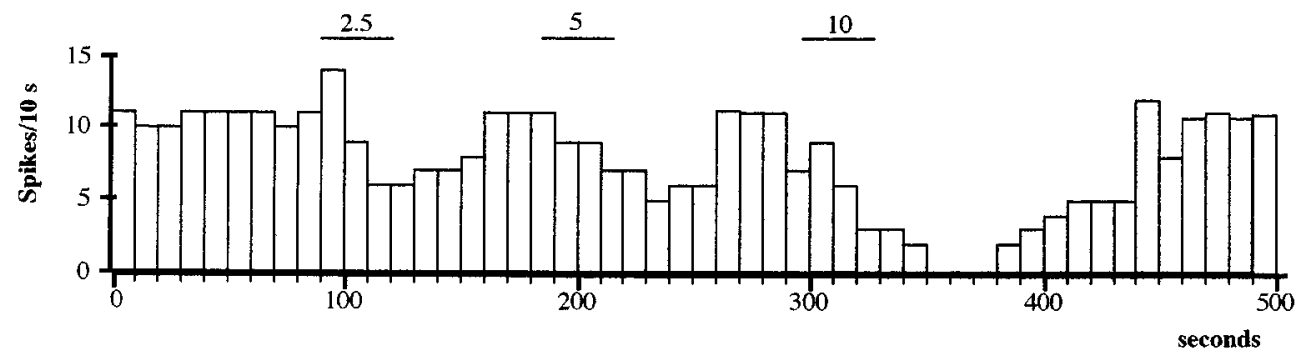

$\mathbf{b}$
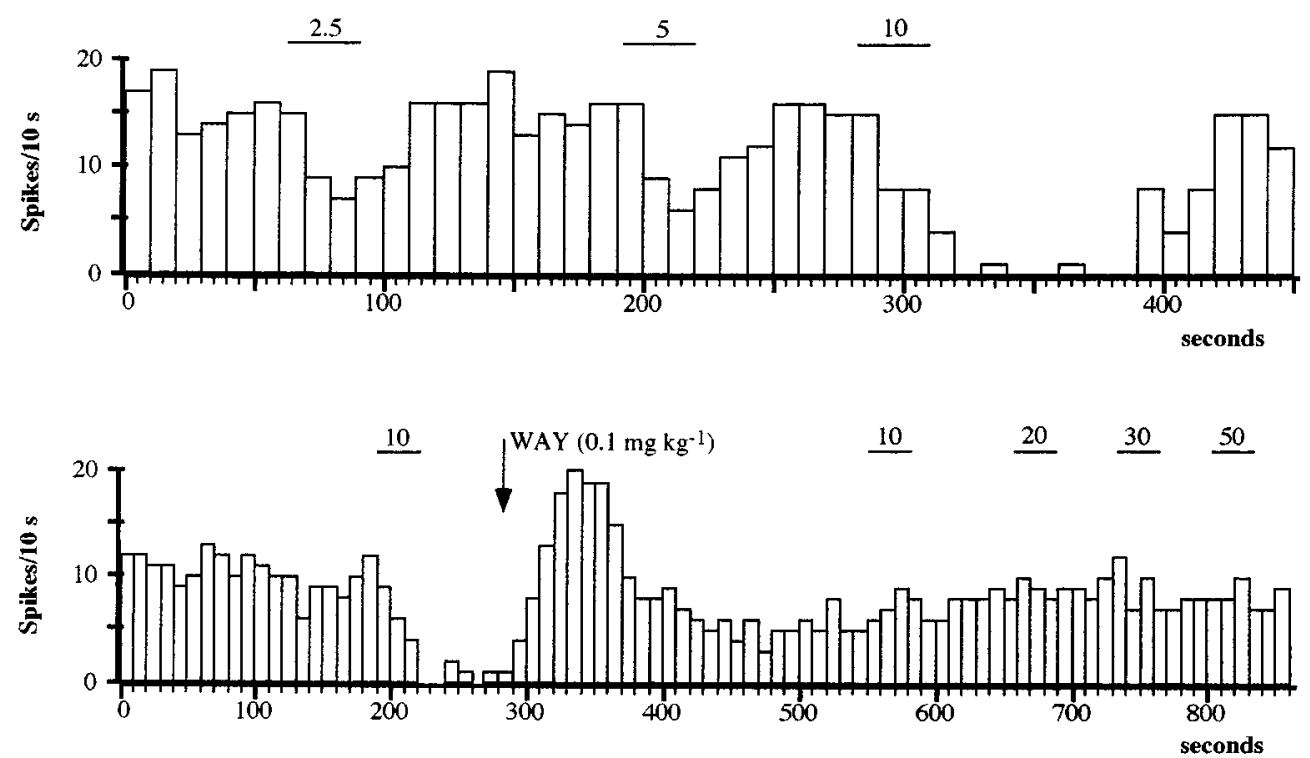

Figure 4 Typical responses of individual 5-HT neurones to iontophoretic 8-OH-DPAT application with increasing currents before (a) and after (b) transection of the frontal cortex. Systemic administration of WAY $100635\left(0.1 \mathrm{mg} \mathrm{kg}^{-1}\right.$, i.v.; indicated by arrow) antagonized the inhibitory effect of iontophoretically applied 8-OH-DPAT (c; neurone recorded after transection). Bars represent the duration of drug application at the current $(\mathrm{nA})$ indicated.

by i.v. injection of $0.1 \mathrm{mg} \mathrm{kg}^{-1}$ WAY 100635 (mPFC 4/5 neurones; $\mathrm{CPu} 3 / 3$ neurones). Bilateral injections of physiological saline into the $\mathrm{mPFC}$ did not change the firing activity of 5 -HT neurones significantly ( $n=4$, data not shown).

\section{Effect of 8-OH-DPAT on the activity of mPFC neurones}

Systemic administration of 8-OH-DPAT $\left(0.5-512 \mu \mathrm{g} \mathrm{kg}^{-1}\right.$, i.v.) had a biphasic effect on the activity of the majority of mPFC neurones tested ( $n=12$ of 13; Figure 6$)$. At lower doses $\left(0.5-32 \mu \mathrm{g} \mathrm{kg}^{-1}\right)$ 8-OH-DPAT evoked excitation of $\mathrm{mPFC}$ neurones $(n=11)$, and at higher doses $\left(32-512 \mu \mathrm{g} \mathrm{kg}^{-1}\right)$ suppressed the activity of mPFC neurones $(n=8)$. There was a high variation in the amplitude of excitation of tested neurones (range from $159-1500 \%$ increase in firing activity), the mean maximal increase being $502 \pm 114 \%(n=11)$. There was also wide variation in the dose of $8-\mathrm{OH}-\mathrm{DPAT}$ which evoked the maximal excitation in $\mathrm{mPFC}$ neurones (range from $1-32 \mu \mathrm{g} \mathrm{kg}^{-1}$ ), with the mean dose producing maximal response being $9.8 \pm 3.6 \mu \mathrm{g} \mathrm{kg}^{-1}$. However, 8-OH-DPAT excited mPFC neurones already at $1 \mu \mathrm{g} \mathrm{kg}^{-1}$ dose ( $200 \pm 51 \%$ increase), a dose which was close to the $\mathrm{ED}_{50}$ value for inhibition of DRN 5-HT neurones (see above). Although no obvious change in firing pattern was observed in the majority of mPFC neurones, in some neurones 8-OHDPAT induced or increased burst activity $(n=2$; data not shown). The excitation of mPFC neurones induced by 8-OHDPAT was reversed by the selective $5-\mathrm{HT}_{1 \mathrm{~A}}$ receptor antagonist WAY 100635 (0.1 $\mathrm{mg} \mathrm{kg}^{-1}$, i.v.) in 4/4 neurones tested (Figure 6).

Following the excitatory effect, further increases in the dose of 8-OH-DPAT led to a suppression of firing activity of $\mathrm{mPFC}$ neurones $(n=8)$ to below predrug levels (range from 4$\left.64 \mu \mathrm{g} \mathrm{kg}^{-1}\right)$. In some neurones $(n=3)$ 8-OH-DPAT caused a total cessation of firing. As with the excitation, the 8-OHDPAT-induced inhibition of mPFC neurones was also reversed by WAY $100635\left(0.1 \mathrm{mg} \mathrm{kg}^{-1}\right.$, i.v. $)$ in all tested neurones ( $n=7$, Figure 6).

\section{Effect of 8-OH-DPAT on Fos expression in the mPFC}

Systemic administration of 8-OH-DPAT $\left(0.1 \mathrm{mg} \mathrm{kg}^{-1}\right.$, s.c. $)$ to non-anaesthetized rats $(n=7)$ evoked a marked and region specific expression of Fos in the mPFC (Figures 7 and 8). Thus, a higher number of Fos-positive neurones was observed in the IL and $\mathrm{Cg} 3$ subregions of the mPFC, but not in the Fr1 region (Figure 7), compared to saline-treated controls $(n=5)$. Pretreatment with the selective $5-\mathrm{HT}_{1 \mathrm{~A}}$ receptor antagonist WAY 100635 ( $1 \mathrm{mg} \mathrm{kg}^{-1}$, s.c.) greatly attenuated the effect of 8-OH-DPAT on Fos expression both in the IL and $\mathrm{Cg} 3$ subregions $(n=4)$. Statistical analysis of the data (one-way ANOVA) revealed significant treatment effects in both IL $\left(\mathrm{F}_{(2,15)}=12.8 \quad P<0.001\right)$ and $\mathrm{Cg} 3 \quad\left(\mathrm{~F}_{(2,15)}=24.5 \quad P<0.0001\right)$ regions but not in the Frl region $\left(\mathrm{F}_{(2,15)}=1.3 \quad P=0.3\right)$. Furthermore, post hoc analysis of the data (Dunnett $t$-test) showed that the effect of 8-OH-DPAT on Fos expression was 
significantly reduced by pretreatment with WAY 100635 in both the IL $(P<0.02)$ and $\mathrm{Cg} 3(P<0.001)$ subregions. In a preliminary study 8-OH-DPAT also induced Fos expression in the $\mathrm{mPFC}$ of chloral hydrate anaesthetized rats $(n=2)$, although the number of Fos-positive neurones was lower than in non-anaesthetized rats (data not shown).
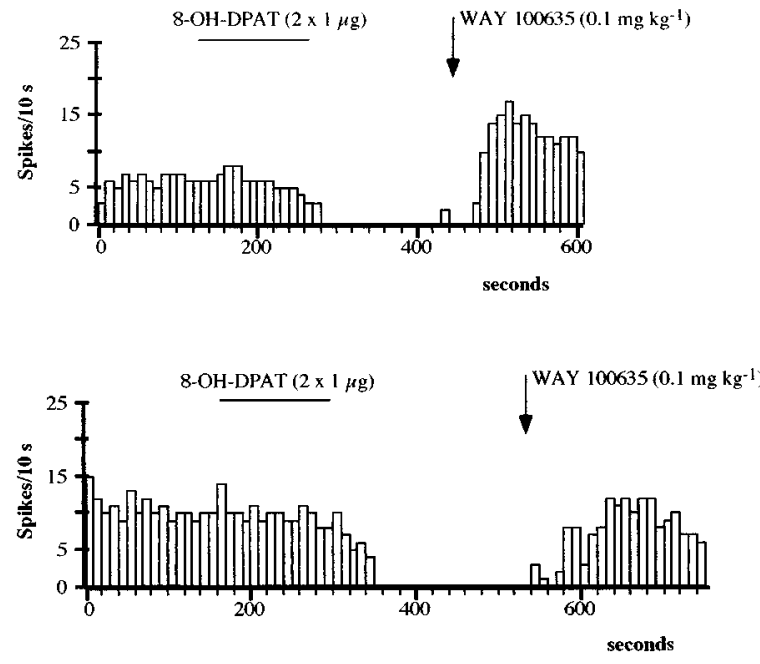

Figure 5 Effect of local, bilateral microinjection of 8-OH-DPAT $\left(1 \mu \mathrm{g} \mu \mathrm{l}^{-1}\right)$ into the mPFC (a) or CPu (b) on the activity of DRN 5HT neurones. Horizontal bars indicate the duration of 8-OH-DPAT infusion. Systemic administration of WAY $100635\left(0.1 \mathrm{mg} \mathrm{kg}^{-1}\right.$, i.v.; indicated by arrows) reversed the inhibition of 5-HT neurones induced by either mPFC or CPu microinjection of 8-OH-DPAT.
Histological localization of the recorded neurones and evaluation of the lesions

All 5-HT neurones included in the present study were localized within the DRN, most of them in the dorsal or ventral subregion and only two neurones were recorded in the lateral wings (Paxinos \& Watson, 1986). Following cortical recordings, iontophoretic dye depositions were localized in the ventral region of the medial prefrontal cortex (in layer 5 or 6), corresponding to the cingulate cortex area 3 and infralimbic cortex.

The success of transection of the frontal cortex, ablation of the mPFC or parietal cortex was histologically confirmed. The tissue ablated included the cingulate cortex areas 1 and 3, frontal cortex area 2, medial orbital cortex and infralimbic cortex (mPFC-ablation) or parietal cortex area 1 and temporal cortex area 1 (parietal cortex-ablation). In rats microinjected with 8-OH-DPAT the injection site was localized in the cingulate cortex area 3 and/or infralimbic cortex.

\section{Discussion}

The present results show that acute transection of the frontal cortex/anterior forebrain significantly attenuated the inhibitory effect of systemic administration of the $5-\mathrm{HT}_{1 \mathrm{~A}}$ receptor agonist 8-OH-DPAT on DRN 5-HT neurones, in an agreement with earlier observations by Ceci et al. (1994). The present study identifies the $\mathrm{mPFC}$ as an important site involved in the effect of the transection. Thus, a discrete ablation of this area attenuated the 8-OH-DPAT-induced inhibition of 5-HT neurones to the same extent as the cortical
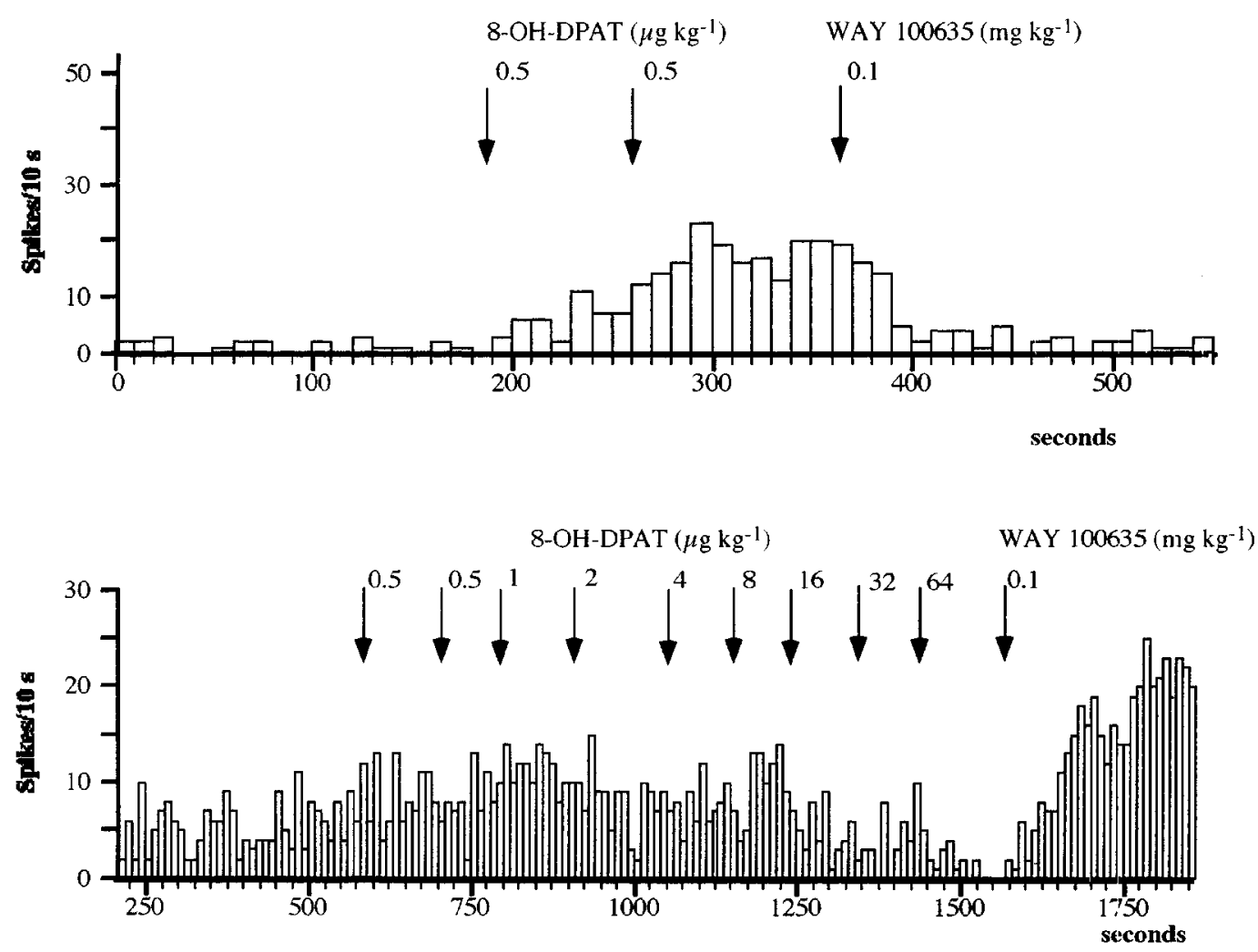

Figure 6 Firing rate histograms of two cortical neurones recorded from the mPFC. (a) Application of 8-OH-DPAT (i.v.) induced an excitation which was reversed by WAY 100635 (arrows indicate drug application). (b) Increasing doses of 8-OH-DPAT led to inhibition and finally cessation of firing activity of the neurone, the 8-OH-DPAT-induced inhibition was reversed by WAY 100635 . 


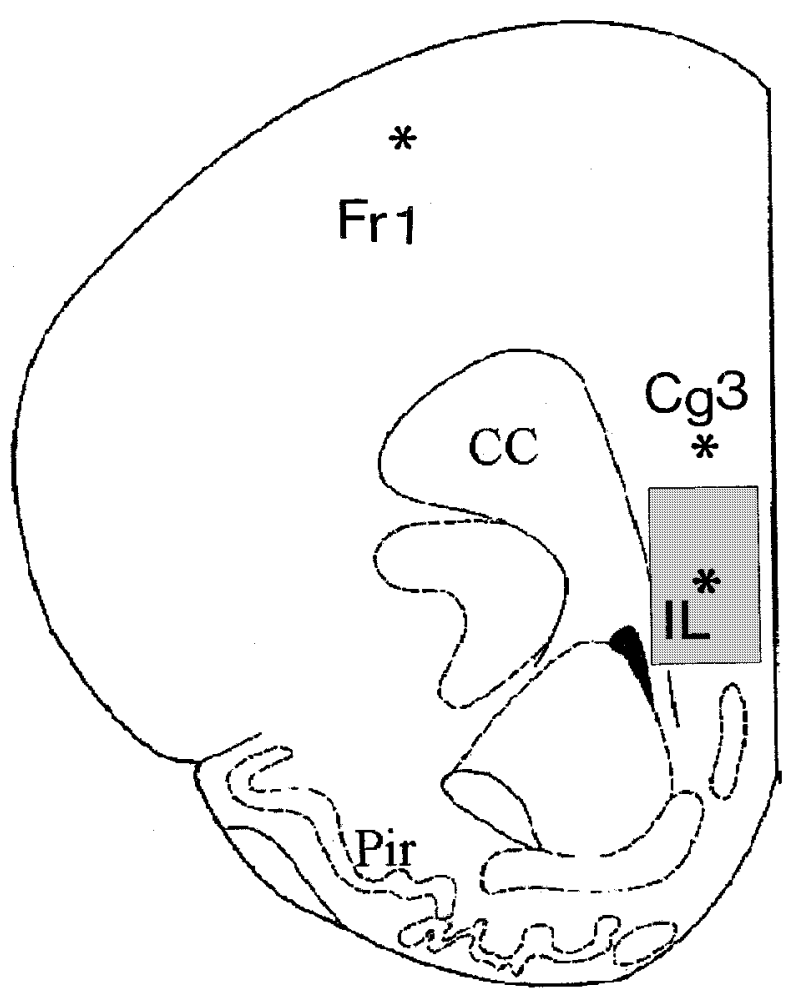

b

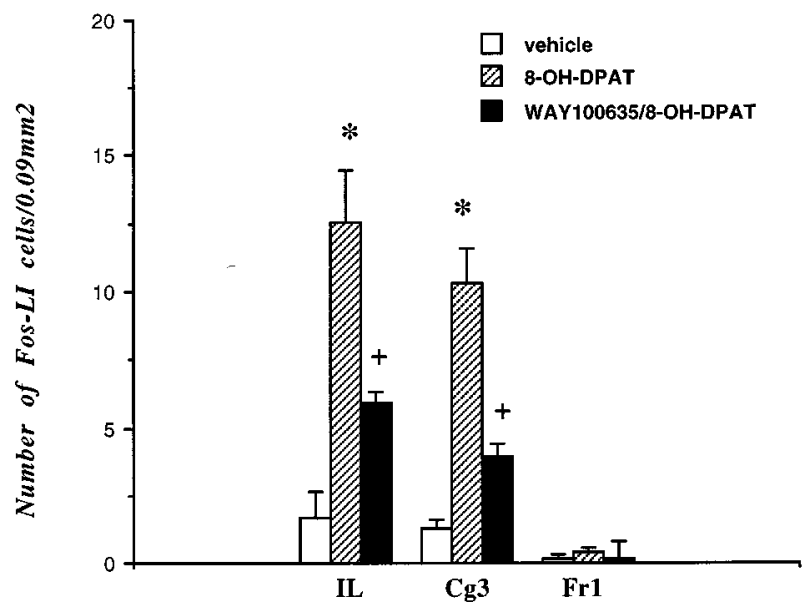

Figure 7 (a) Schematic drawing of a frontal section of the rat brain at anterior $+2.7 \mathrm{~mm}$ (according to Paxinos \& Watson, 1986) illustrating regions of the prefrontal cortex (asterisks) in which the number of Fos-positive neurones were determined. Fos positive neurones were counted in a tissue area of $0.09 \mathrm{~mm}^{2}$ in the frontal cortex area $1(\mathrm{Fr} 1)$, cingulate cortex $(\mathrm{Cg} 3)$ and infralimbic cortex (IL). The grey area represents part of the mPFC shown on the photomicrographs (Figure 8). (b) Effects of saline $(n=5), 8-\mathrm{OH}-$ DPAT $\left(0.1 \mathrm{mg} \mathrm{kg}^{-1}\right.$, s.c.; $\left.n=7\right)$ and WAY $100635\left(1 \mathrm{mg} \mathrm{kg}^{-1}\right.$, s.c. $) /$ 8-OH-DPAT $\left(0.1 \mathrm{mg} \mathrm{kg}^{-1}\right.$, s.c.; $\left.n=4\right)$ on the number of Fos-positive neurones in different areas of the frontal cortex. $* P<0.001$ compared to vehicle treatment, ${ }^{+} P<0.02$ compared to 8 -OH-DPAT treatment (one-way ANOVA followed by Dunnett $t$-test).

transection. In contrast, ablation of the parietal cortex failed to modify the inhibitory effect of 8-OH-DPAT, demonstrating the selective nature of the mPFC ablations. Importantly, we also demonstrate that cortical transection did not alter the potency of iontophoretically applied 8-OH-DPAT to inhibit 5-
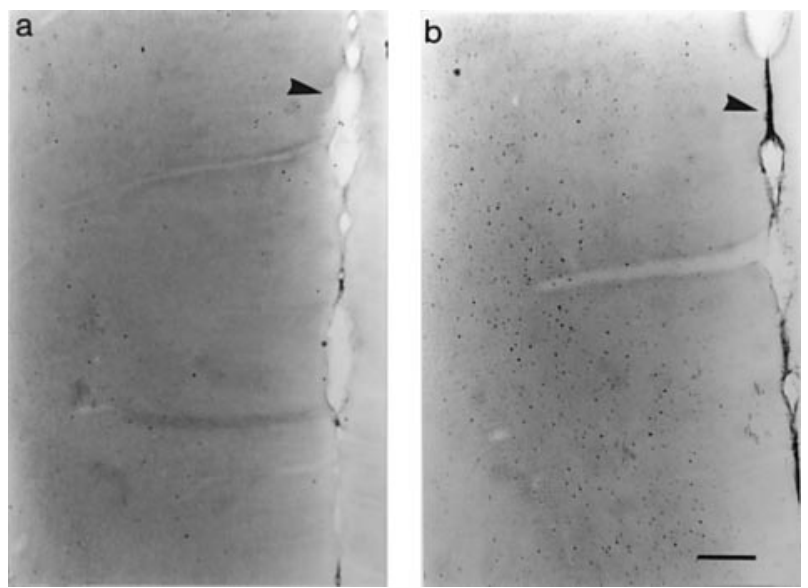

Figure 8 Effects of saline (a) or 8-OH-DPAT (b; $0.1 \mathrm{mg} \mathrm{kg}^{-1}$, s.c.) injection to non-anaesthetized rats on the distribution of Fos in the mPFC. Photomicrographs represent the ventral part of the cingulate cortex $(\mathrm{Cg} 3)$ and infralimbic cortex (as indicated on Figure 7). Arrows point to the midline; calibration bar represents $200 \mu \mathrm{m}$.

HT neurones. The latter data indicate that cortical transection/ mPFC ablation does not alter the responsiveness of somatodendritic 5- $\mathrm{HT}_{1 \mathrm{~A}}$ receptors in the DRN. From these data taken together we conclude that the inhibition of 5-HT neurones by systemically administered 8-OH-DPAT involves activation of not only somatodendritic $5-\mathrm{HT}_{1 \mathrm{~A}}$ receptors in the DRN but also another population of $5-\mathrm{HT}_{1 \mathrm{~A}}$ receptors which are located postsynaptically. Our evidence suggests that the latter receptor population are either located in the $\mathrm{mPFC}$ or modulate neural circuits related to the mPFC.

The present findings are in agreement with several previous indirect observations indicating that activation of postsynaptic $5-\mathrm{HT}_{1 \mathrm{~A}}$ receptors could influence the activity of 5-HT neurones (Blier \& de Montigny, 1980; 1987; Blier et al., 1987; Schechter et al., 1990; Jolas et al., 1994). In addition, a recent abstract reported that in animals receiving an intra-DRN injection of pertussis toxin to deactivate somatodendritic 5-HT $\mathrm{HA}_{1 \mathrm{~A}}$ autoreceptors, 8-OH-DPAT did not inhibit any DRN 5-HT neurones when it was locally applied, whereas half of the neurones tested were inhibited when 8-OH-DPAT was administered systemically (Martin-Ruiz \& Ugedo, 1998).

Although cortical transection significantly attenuated the inhibitory effect of systemic 8-OH-DPAT on DRN 5-HT neurones, the same lesion did not alter the response of 5-HT neurones to systemic administration of paroxetine, a selective 5-HT re-uptake inhibitor. Previous data indicate that paroxetine-induced inhibition of DRN 5-HT neurones involves activation of somatodendritic $5-\mathrm{HT}_{1 \mathrm{~A}}$ autoreceptors following increased extracellular 5-HT in the DRN (Bell \& Artigas, 1992; Gartside et al., 1995; Hajós et al., 1995a). The present data indicate that this may be the main mechanism and that postsynaptic $5-\mathrm{HT}_{1 \mathrm{~A}}$ receptors are not involved. It is noteworthy that paroxetine at doses used in the present study increases extracellular 5-HT in the DRN but not in the frontal cortex (Gartside et al., 1995). Our results with paroxetine are in line with earlier reports that the inhibition of DRN 5-HT neurones by acute injection of a 5-HT re-uptake inhibitor is not abolished by a transection which cuts any possible feedback to the DRN from postsynaptic forebrain regions (Mosko \& Jacobs, 1977; Aghajanian, 1978).

How can the mPFC be involved in the inhibitory effect of 8OH-DPAT on 5-HT neuronal activity in the DRN? In this study we found that systemic administration of $8-\mathrm{OH}-\mathrm{DPAT}$ 
activated neurones recorded in the $\mathrm{mPFC}$ and did so in the same dose range which inhibited the activity of DRN 5-HT neurones. This effect was reversed by the selective $5-\mathrm{HT}_{1 \mathrm{~A}}$ receptor antagonist WAY 100635, indicating the involvement of $5-\mathrm{HT}_{1 \mathrm{~A}}$ receptors. These data were supported by our experiments showing that 8-OH-DPAT (administered to conscious rats) induced the expression of Fos immunoreactivity, a well established marker of neuronal activation (Morgan \& Curran, 1991), in the mPFC. Indeed, the strongest increases in Fos immunoreactivity were apparent in those same regions of the mPFC ( $\mathrm{Cg} 3$ and IL) in which the electrophysiological measurements were made. Interestingly, Borsini et al. (1995) also reported excitation of $\mathrm{mPFC}$ neurones following systemic administration of 8-OH-DPAT and buspirone. Moreover, the latter study established that the excitatory effect was still present in animals with 5-HT neuronal lesions, indicating that the effect was mediated by postsynaptic $5-\mathrm{HT}_{1 \mathrm{~A}}$ receptors.

The excitatory effects of 8-OH-DPAT on $\mathrm{mPFC}$ neurones is of particular interest in view of anatomical evidence that there is a direct and prominent connection between the MPFC and the midbrain raphe nuclei (Arnsten \& Goldman-Rakic, 1984; Hajós et al., 1998b; Peyron et al., 1998), and that when stimulated electrically this pathway has a strong inhibitory influence on the firing of DRN 5-HT neurones (Hajós et al., 1998b). This influence may be mediated, at least in part, by glutamatergic cortical projection neurones which form synapses preferentially with GABA neurones in the DRN (Székely et al., 1998). Therefore, it is tempting to speculate that the excitation of mPFC neurones by 8-OH-DPAT plays a key role in the drug's inhibitory effect on 5-HT neuronal activity.

If the mPFC is involved in the inhibitory effects of $8-\mathrm{OH}$ DPAT on DRN 5-HT neurones, is the effect mediated by the dense population of 5- $\mathrm{HT}_{1 \mathrm{~A}}$ receptors located in this region? In support of this idea, the present study shows that microinjection of 8-OH-DPAT into the mPFC inhibited the electrical activity of 5-HT neurones in the DRN via a $5-\mathrm{HT}_{1 \mathrm{~A}}$ receptor mediated mechanism. However, since 8-OH-DPAT was similarly effective following local application into the $\mathrm{CPu}$, a region with low 5- $\mathrm{HT}_{1 \mathrm{~A}}$ receptors (Vergé et al., 1986), it is a matter of concern that the locally applied 8-OH-DPAT rapidly transfers to the DRN by diffusion or reabsorption into the circulation. Indeed, Jolas et al. (1995) have reported that intrahippocampal application of 8-OH-DPAT inhibits 5-HT cell firing in the DRN but, on the basis of lesion studies and measurements of the distribution of radiolabelled $8-\mathrm{OH}-$ DPAT, concluded that the effect was mediated by drug diffusion to the DRN. Although intracerebral microinjection of 8-OH-DPAT is a frequently performed procedure in neuropharmacological studies, and is assumed to involve little spread of drug, evidence is accumulating that this is not the case.

Although the local injection work does not allow us to firmly conclude that $5-\mathrm{HT}_{1 \mathrm{~A}}$ receptors in the $\mathrm{mPFC}$ are involved in the 8-OH-DPAT-induced inhibition of 5-HT cell firing, this seems unlikely on the basis of what is currently known about the cellular localization of $5-\mathrm{HT}_{1 \mathrm{~A}}$ receptors in cortex. Thus, evidence from in situ hybridization and immunocytochemical experiments (e.g. Pompeiano et al., 1992; Burnet et al., 1995; Kia et al., 1996) and studies with cytotoxic lesions (Francis et al., 1992), indicates that cortical 5$\mathrm{HT}_{1 \mathrm{~A}}$ receptors are localized on glutamatergic pyramidal output neurones. Given the well established fact that at the membrane level 5- $\mathrm{HT}_{1 \mathrm{~A}}$ receptors are inhibitory on all neurones tested so far (including cortical neurones), it is not easy to explain the excitation of $\mathrm{mPFC}$ neurones by $8-\mathrm{OH}-$ DPAT without inferring that the receptors are also localized on inhibitory interneurones or on the terminals of the collaterals of the output neurones. Activation of $5-\mathrm{HT}_{1 \mathrm{~A}}$ receptors on cortical pyramidal neurones could, however, explain the inhibition of cortical neurones induced by systemic administration of higher doses of 8-OH-DPAT. The latter effect has been observed in a previous study and demonstrated to be mediated by $5-\mathrm{HT}_{1 \mathrm{~A}}$ receptors (Araneda \& Andrade, 1991).

A more likely scenario is that the excitation of mPFC neurones by systemically administered 8-OH-DPAT is mediated indirectly via an action on other pathways projecting to the mPFC. Candidate pathways include noradrenergic and dopaminergic projections to the cortex since these transmitters can lead to excitation of cortical neurones (McCormick et al., 1993; Hasselmo, 1995) and 8-OH-DPAT has been shown to increase the release of cortical noradrenaline (Hajós-Korcsok \& Sharp, 1996; Gobert et al., 1998) and dopamine (Arborelius et al., 1993; Tanda et al., 1994; Gobert et al., 1998) in microdialysis studies.

In conclusion, the present study finds further evidence to support the view that the inhibitory effect of 8-OH-DPAT on the firing activity of DRN 5-HT neurones involves, in part, activation of a $5-\mathrm{HT}_{1 \mathrm{~A}}$ receptor mediated postsynaptic feedback loop centred on the mPFC. The site of the postsynaptic $5-\mathrm{HT}_{1 \mathrm{~A}}$ receptor is not clear but evidence at this stage indicates the involvement of afferents to the $\mathrm{mPFC}$ rather than the dense population of $\mathrm{mPFC} 5-\mathrm{HT}_{1 \mathrm{~A}}$ receptors per se. Evidence in this paper suggests that 5-HT reuptake inhibitors (which only weakly increase extracellular 5-HT in some forebrain regions) inhibit 5-HT neurones via the somatodendritic $5-\mathrm{HT}_{1 \mathrm{~A}}$ autoreceptor without activating the postsynaptic feedback loop. The site of the postsynaptic $5-\mathrm{HT}_{1 \mathrm{~A}}$ receptor mediating feedback inhibition of DRN 5-HT neurones, and its pharmacological properties are worthy of further investigation.

This work was supported by the Medical Research Council (U.K.).

\section{References}

AGHAJANIAN, G.K. (1978). Feedback regulation of central monoaminergic neurons: Evidence from single cell recording studies. In Essays in Neurochemistry and Neuropharmacology, ed Youdim, M.B.H., Lovenberg, W., Sharman, D.F. \& Lagnado, J.R., Volume 3, pp. 2-32. Chichester: John Wiley \& Sons.

AGHAJANIAN, G.K., HAIGLER, H.J. \& BLOOM, F.E. (1972). Lysergic acid diethylamide and serotonin: direct action on serotonincontaining neurons in rat brain. Life. Sci., 11, 615-622.

AGHAJANIAN, G.K. \& LAKOSKI, J.M. (1984). Hyperpolarization of serotonergic neurones by serotonin and LSD: studies in brain slices showing increased $\mathrm{K}^{+}$conductance. Brain Res., 305, 181 185.

AGHAJANIAN, G.K. \& VANDERMAELEN, C.P. (1982). Intracellular identification of central noradrenergic and serotonergic neurons by a new double labeling procedure. J. Neurosci., 2, 1786-1792. 
AGHAJANiAn, G.K., WANG, R.Y. \& BARABAN, J. (1978). Serotonergic and non-serotonergic neurons of the dorsal raphe: reciprocal changes in firing induced by peripheral nerve stimulation. Brain Res., 153, $169-175$.

ARANEDA, R. \& ANDRADE, R. (1991). 5-Hydroxytryptamine2 and 5-hydroxytryptamine1A receptors mediate opposing responses on membrane excitability in rat association cortex. Neuroscience, 40, $399-412$.

ARBORELIUS, L., NOMIKOS, G.G., HACKSELL, U. \& SVENSSON, T.H. (1993). ( $R$ )-8-OH-DPAT preferentially increases dopamine release in the rat median prefrontal cortex. Acta Physiol. Scand., 148, $465-466$.

ARNSTEN, A.F.T. \& GOLDMAN-RAKIC, P.S. (1984). Selective prefrontal cortical projections to the region of the locus coeruleus and raphe nuclei in the rhesus monkey. Brain Res., 306, 9-18.

BELL, N. \& ARTIGAS, F. (1992). Fluvoxamine preferentially increases extracellular 5-hydroxytryptamine in the raphe nuclei: an in vivo microdialysis study. Eur. J. Pharmacol., 229, $101-103$.

BLIER, P. \& DE MONTIGNY, C. (1980). Effect of chronic tricyclic antidepressant treatment on the serotoninergic autoreceptors: A microiontophoretic study in the rat. Naunyn-Schmiedeberg's Arch. Pharmacol., 314, $123-128$.

BLIER, P. \& DE MONTIGNY, C. (1983). Electrophysiological studies on the effect of repeated zimelidine administration on serotonergic neurotransmission on the rat. J. Neurosci., 3, 1270-1278.

BLIER, P. \& DE MONTIGNY, C. (1987). Modification of 5-HT neuron properties by sustained administration of the $5-\mathrm{HT}_{1 \mathrm{~A}}$ agonist gepirone: Electrophysiological studies in the rat brain. Synapse, 1, $470-480$.

BLIER, P. \& DE MONTIGNY, C. (1994). Current advances and trends in the treatment of depression. Trends Pharmacol. Sci., 15, $220-$ 226.

BLIER, P., DE MONTIGNY, C. \& TARDIF, D. (1987). Short-term lithium treatment enhances responsiveness of postsynaptic 5$\mathrm{HT}_{1 \mathrm{~A}}$ receptors without altering 5-HT autoreceptor sensitivity: An electrophysiological study in the rat. Synapse, 1, 225-232.

BORSINI, F., CECI, A., BIETTI, G. \& DONETTI, A. (1995). BIMT17, a $5-\mathrm{HT}_{1 \mathrm{~A}}$ receptor agonist $/ 5-\mathrm{HT}_{2 \mathrm{~A}}$ receptor antagonist, directly activates postsynaptic 5-HT inhibitory responses in the rat cerebral cortex. Naunyn-Schmiedeberg's Arch. Pharmacol., 352, $283-290$.

BURNET, P.W.J., EASTWOOD, S.L., LACEY, K. \& HARRISON, P.J. (1995). The distribution of 5- $\mathrm{HT}_{1 \mathrm{~A}}$ and $5-\mathrm{HT}_{2 \mathrm{~A}}$ receptor mRNA in human brain. Brain Res., 676, 157-168.

CECI, A., BASCHIROTTO, A. \& BORSINI, F. (1994). The inhibitory effect of 8-OH-DPAT on the firing activity of dorsal raphe serotoninergic neurons in rats is attenuated by lesion of the frontal cortex. Neuropharmacology, 33, 709-713.

FLETCHER, A., FORSTER, E.A., BILL, D.J., BROWN, G., CLIFFE, I.A., HARTLEY, J.E., CHILDS, H.J., MIDDLEFELL, V.C., LANFUMEY, L., CORRADETTI, R., LAPORTE, A-M., GOZLAN, H., HAMON, M. \& DOURISH, C.T. (1996). Electrophysiological, biochemical, neurohormonal and behavioural studies with WAY 100635, a potent, selective and silent $5-\mathrm{HT}_{1 \mathrm{~A}}$ receptor antagonist. Behav. Brain Res., 73, $337-357$.

FRANCIS, P.T., PANGALOS, M.N., PEARSON, R.C.A., MIDDLEMISS, D.N., STRATMANN, G.C. \& BOWEN, D.M. (1992). 5-Hydroxytryptamine $_{1 \mathrm{~A}}$ but not 5-hydroxytryptamine 2 receptors are enriched on neocortical pyramidal neurones destroyed by intrastriatal volkensin. J. Pharmacol. Exp. Ther., 261, 12731281.

GARTSIDE, S.E., UMBERS, V., HAJÓS, M. \& SHARP, T. (1995). Interaction between a selective $5-\mathrm{HT}_{1 \mathrm{~A}}$ receptor antagonist and an SSRI in vivo: effects on 5-HT cell firing and extracellular 5HT. Br. J. Pharmacol., 115, $1064-1070$.

GOBERT, A., RIVET, J.-M., AUDINOT, V., NEWMAN-TANCEREDI, A., Cistarelli, L. \& MILlAN, M.J. (1998). Simultaneous quantification of serotonin, dopamine and noradrenaline levels in single frontal cortex dialysates of freely-moving rats reveals a complex pattern of reciprocal auto- and heteroreceptor-mediated control of release. Neuroscience, 84, 413-429.

HAJÓS, M., GARTSIDE, S.E. \& SHARP, T. (1995a). Inhibition of median and dorsal raphe neurones by the selective serotonin reuptake inhibitor paroxetine. Naunyn-Schmiedeberg's Arch. Pharmacol., 351, 624-629.

HAJÓS, M., GARTSIDE, S.E., SHARP, T., HYLAND, B.I., TETKO, I. \& VILLA, A.E.P. (1998a). 5-HT ${ }_{1 \mathrm{~A}}$ receptor-mediated modulation of neuronal activity of the medial prefrontal cortex. Eur. J. Neurosci., 10 (Suppl. 10), 347.
HAJÓS, M., GARTSIDE, S.E., VILLA, A.E.P. \& SHARP, T. (1995b). Evidence of a repetitive (burst) firing pattern in a sub-population of 5-HT neurons in the dorsal and median raphe nuclei of the rat. Neuroscience, 69, $189-197$.

HAJÓS, M., RICHARDS, C.D., SZÉKELY, A.D. \& SHARP, T. (1998b). An electrophysiological and neuroanatomical study of the medial prefrontal cortex projection to the midbrain raphe nuclei in the rat. Neuroscience, 87, 95-108.

HAJÓS, M., SHARP, T. \& NEWBERRY, N.R. (1996a). Intracellular recordings from burst-firing presumed serotonergic neurones in the rat dorsal raphe nucleus in vivo. Brain Res., 737, 308-312.

HAJÓS, M., VILLA, A.E.P. \& SHARP, T. (1996b). Pharmacological properties of burst-like firing serotonergic neurones in the rat dorsal raphe nucleus. Soc. Neurosci. (Abstract) Vol. 22, Washington, U.S.A.

HAJÓS-KORCSOK, É. \& SHARP, T. (1996). 8-OH-DPAT-induced release of noradrenaline in rat hippocampus in vivo: evidence for a role of both 5- $\mathrm{HT}_{1 \mathrm{~A}}$ and $\mathrm{D}_{1}$ receptors. Eur. J. Pharmacol., 314, $285-291$.

HASSELMO, M.E. (1995). Neuromodulation and cortical function: modelling the physiological basis of behavior. Behav. Brain. Res., 67, $1-27$.

JOLAS, T., HAJ-DAHMANE, S., KIDD, E.J., LANGLOIS, X., LANFUMEY, L., FATTACCINI, C.M., VANTALON, V., LAPORTE, A.M., ADRIEN, J., GOZLAN, H. \& HAMON, M. (1994). Central pre- and postsynaptic $5-\mathrm{HT}_{1 \mathrm{~A}}$ receptors in rats treated chronically with a novel antidepressant, cericlamine. J. Pharmacol. Exp. Ther., 268 , $1432-1443$.

JOLAS, T., SCHREIBER, R., LAPORTE, A.M., CHASTANET, M., DE VRY, J., GLASER, T., ADRIEN, J. \& HAMON, M. (1995). Are postsynaptic $5-\mathrm{HT}_{1 \mathrm{~A}}$ receptors involved in the anxiolytic effects of $5-\mathrm{HT}_{1 \mathrm{~A}}$ receptor agonists and in their inhibitory effects on the firing of serotonergic neurons in the rat? J. Pharmacol. Exp. Ther., 272, $920-929$.

KIA, H.K., MIQUEL, M.-C., BRISORGUEIL, M.-J., DAVAL, G., RIAD, M., EL MESTIKAWY, S., HAMON, M. \& VERGÉ, D. (1996). Immunocytochemical localisation of $\operatorname{serotonin}_{1 \mathrm{~A}}$ receptors in the rat central nervous system. J. Comp. Neurol., 365, 289-305.

LEVINE, E.S. \& JACOBS, B.L. (1992). Neurochemical afferents controlling the activity of serotonergic neurons in the dorsal raphe nucleus: microiontophoretic studies in the awake cat. $J$. Neurosci., 12, $4037-4044$.

MARTIN-RUIZ， R. \& UGEDO, L. (1998). Postsynaptic 5-HT 1 A receptors are involved in dorsal raphe nucleus 5-HT neurones activity. Eur. J. Neurosci., 10 (Suppl. 10), 349.

MCCORMICK, A.D., WANG, Z. \& HUGUENARD, J. (1993). Neurotransmitter control of neocortical activity and excitability. Cerebral Cortex, 3, 387-398.

MOORMAN, J.M., JACKSON, A., GRAHAME-SMITH, D G. \& LESLIE, R.A. (1995). Induction of c-fos in rat forebrain by pharmacological manipulation of 5-hydroxytryptamine levels. Neuroscience, 68, $1089-1096$.

MORGAN, J.I. \& CURRAN, T. (1991). Stimulus-transcription coupling in the nervous system: involvement of the inducible proto-oncogenes fos and jun. Annu. Rev. Neurosci., 14, 421-451.

MOSKO, S.S. \& JACOBS, B.L. (1977). Electrophysiological evidence against negative neuronal feedback from the forebrain controlling midbrain raphe unit activity. Brain Res., 119, 291-303.

PAXINOS, G. \& WATSON, C. (1986). In: The rat brain in stereotaxic coordinates. Sydney: Academic Press.

PENINGTON, N.J., KELLY, J.S. \& FOX, A.P. (1993a). Whole-cell recordings of inwardly rectifying $\mathrm{K}^{+}$currents activated by 5 $\mathrm{HT}_{1 \mathrm{~A}}$ receptors on dorsal raphe neurones in the adult rat. $J$. Physiol. (Lond), 469, 387-405.

PENINGTON, N.J., KELLY, J.S. \& FOX, A.P. (1993b). Unitary properties of potassium channels activated by 5-HT in acutely isolated rat dorsal raphe neurones. J. Physiol. (Lond), 469, 407426.

PEYRON, C., PETIT, J.-M., RAMPON, C., JOUVET, M. \& LUPPI, P.-H. (1998). Forebrain afferents to the rat dorsal raphe nucleus demonstrated by retrograde and anterograde tracing methods. Neuroscience, 82, $443-468$.

POMPEIANO, M., PALACIOS, J.M. \& MENGOD, G. (1992). Distribution and cellular localization of mRNA coding for $5-\mathrm{HT}_{1 \mathrm{~A}}$ receptor in the rat brain: correlation with receptor binding. $J$. Neurosci., 12, $440-453$. 
SCHECHTER, L.E., BOLANOS, F.J., GOZLAN, H., LANFUMEY, L., HAJ-DAHMANE, S., LAPORTE, A.M., FATTACCINI, C.M. \& HAMON, M. (1990). Alterations of central serotoninergic and dopaminergic neurotransmission in rats chronically treated with ipsapirone: Biochemical and electrophysiological studies. $J$. Pharmacol. Exp. Ther., 255, $1335-1347$.

SPROUSE, J.S. \& AGHAJANIAN, G.K. (1987). Electrophysiological responses of serotonergic dorsal raphe neurons to $5-\mathrm{HT}_{1 \mathrm{~A}}$ and 5 $\mathrm{HT}_{1 \mathrm{~B}}$ agonists. Synapse, 1, 3-9.

SZÉKELY, A.D., HAJÓS, M. \& CSILlAG, A. (1998). Prefrontal afferents in the midbrain dorsal raphe nucleus of the rat. Eur. J. Neurosci., 10 (Suppl. 10), 246.
TANDA, G., CARBONI, E., FRAU, R. \& DI CHIARA, G. (1994). Increase of extracellular dopamine in the prefrontal cortex: a trait of drugs with antidepressant potential? Psychopharmacology, 115, 285-288.

VERGE, D., DAVAL, G., MARCINKIEWICZ, M., PATEY, A., EL MESTIKAWY, S., GOZLAN, H. \& HAMON, M. (1986). J. Neurosci., 6, $3474-3482$.

(Received December 7, 1998 Accepted February 3, 1999) 